\title{
NOTE
}

\section{Meagre Argyrosomus regius (Osteichthyes) as host of a gonad-infecting species of Philometra (Nematoda: Philometridae) off the Atlantic coast of Portugal}

\author{
František Moravec $^{1, *}$, Nuno Prista ${ }^{2,3}$, Maria José Costa $^{2,3}$ \\ ${ }^{1}$ Institute of Parasitology, Biology Centre of the Academy of Sciences of the Czech Republic, Branišovská 31, \\ 37005 České Budějovice, Czech Republic \\ ${ }^{2}$ Instituto de Oceanografia, Faculdade de Ciências da Universidade de Lisboa, Campo Grande, 1749-016 Lisboa, Portugal \\ ${ }^{3}$ Departamento de Biologia Animal, Faculdade de Ciências da Universidade de Lisboa, Campo Grande, \\ 1749-016 Lisboa, Portugal
}

\begin{abstract}
Subgravid females (up to $439 \mathrm{~mm}$ long) of the nematode Philometra sp. were found in meagre Argyrosomus regius (Asso, 1801) (Sciaenidae: Perciformes) off the southern Atlantic coast of Portugal in 2006. The general morphology of these nematodes somewhat resembles that of Philometra lateolabracis (Yamaguti, 1935), but the gravid females of the species from A. regius are apparently much longer. This is the first documented record of a gonad-infecting species of Philometra in marine fishes off the Atlantic coast of Europe. The possible importance of the gonad-parasitizing Philometra spp. as pathogens of marine fishes is stressed.
\end{abstract}

KEY WORDS: Parasitic nematode $\cdot$ Philometra Fish gonad · Marine fish · Argyrosomus regius • North Atlantic Ocean · Portugal

\section{INTRODUCTION}

Species of the nematode genus Philometra Costa, 1845 parasitic in the gonads of numerous marine fishes are widely distributed mainly in the tropical and subtropical regions of the Atlantic, Indian and Pacific Oceans (Moravec 2006). The ovoviviparous females are large-sized, with a body length from a few centimetres up to about $1 \mathrm{~m}$ in different species, whereas the conspecific males are generally of much smaller size, usually from 2 to $4 \mathrm{~mm}$ long. To date, 17 nominal species of the gonad-infecting Philometra spp. are known from marine fishes (Moravec 2006, Moravec et al. 2006a, Moravec \& Salgado-Maldonado 2007) but the males remain unknown for many Philometra species, which makes the identification of these nematodes difficult. In Europe, the gonad-infecting
Philometra spp. have been reported from marine, mainly perciform fishes in the Mediterranean region and the Black Sea (e.g. Rudolphi 1819, WillemoesSuhm 1871, Stossich 1896, Janiszewska 1949, LópezNeyra 1951, Kovaleva \& Khromova 1967, Petter \& Radujkovic 1986, 1989, Moravec et al. 2003, 2006b, Merella et al. 2004, Moravec \& Genc 2004, Moravec 2006). However, to date Philometra have remained unreported in marine fish caught off the European Atlantic coast.

Meagre Argyrosomus regius (Asso, 1801) (Sciaenidae: Perciformes) is a large marine and brackishwater fish (attaining over $180 \mathrm{~cm}$ and $50 \mathrm{~kg}$ total weight) whose distribution extends from Iceland to the Gulf of Guinea (including the Mediterranean and Black Seas) being regularly present between France and Senegal (and in the eastern Mediterranean) 
(Quéméner 2002). The fish supports minor (although lucrative) local fisheries, both recreational and commercial, throughout the European coasts and has become increasingly important to European aquaculture in recent years (Quéméner 2002, Costa et al. 2006). The species reproduction has so far only been thoroughly studied in Mauritania (Tixerant 1974) and Morocco (Hermas 1995) with only minor descriptions being made of the parasites found on $A$. regius gonads.

Recent parasitological examinations of wild Argyrosomus regius captured off the Portuguese coast in 2006 revealed the presence of female Philometra specimens. The fish specimens, 1 male and 1 female, were mature individuals captured in March and June in Vila Real de Santo António and Olhão (male: total length = $144 \mathrm{~cm}$, total weight $=19.0 \mathrm{~kg}$; female: total length $=$ $158 \mathrm{~cm}$, total weight $=33.0 \mathrm{~kg}$ ). The parasite specimens were collected from the fish gonads after being macroscopically detected from the exterior and were fixed and preserved in $96 \%$ ethanol. During this study, most of the specimens obtained were body fragments of subgravid Philometra; however, 2 complete specimens were also recovered. The specimens have been deposited in the Institute of Parasitology, BCASCR, České Budějovice, Czech Republic (Cat. No. N-70).

The bodies of the 2 fixed, complete subgravid nematode females (Figs. 1 \& 2) are brown, 180 and $439 \mathrm{~mm}$ long and 585 to $843 \mu \mathrm{m}$ maximally wide, respectively, somewhat tapering towards both ends; the posterior part of the body is distinctly narrower than the anterior part. The ratio of the maximum body width to the body length is 1:521-585. The cuticle is smooth. The cephalic end is rounded, 135 to $150 \mu \mathrm{m}$ wide; cephalic papillae are very small and indistinct when viewed laterally under the light microscope. Scanning electron microscopy revealed the presence of 4 submedian pairs of minute papillae of the external circle and 1 pair of minute lateral papillae of the internal circle (Fig. 1D), encircling the circular oral aperture; the mouth bottom is formed by the flat surfaces of the 3 oesophageal sectors. The oesophagus is narrow, somewhat swollen near the mouth to form a distinct inflation $63 \mu \mathrm{m}$ long and 75 to $78 \mu \mathrm{m}$ wide, which is not separated from the posterior cylindrical part of the oesophagus. The overall length of the oesophagus is 2.09 to $2.52 \mathrm{~mm}$, representing 0.6 to $1.2 \%$ of the body length;
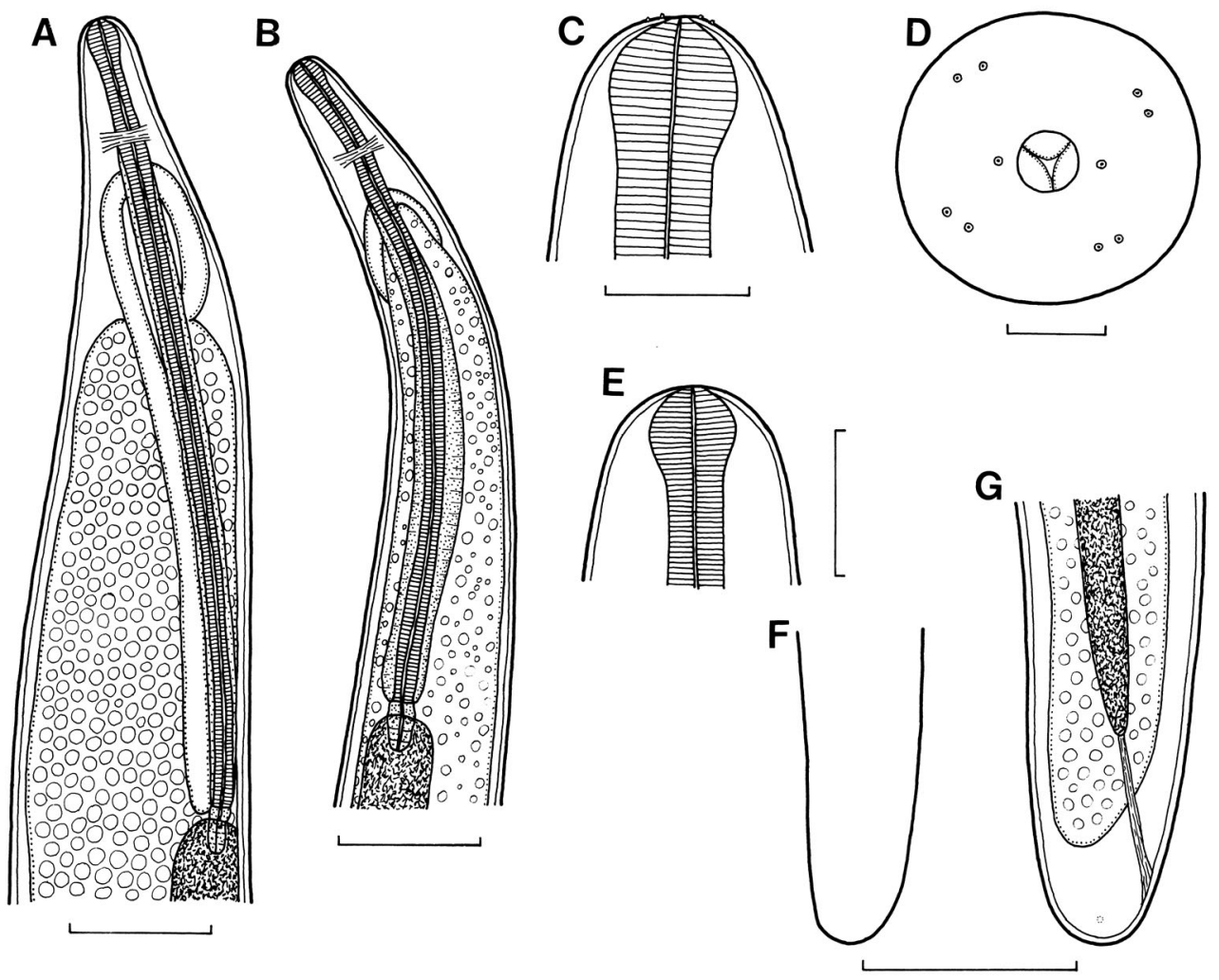

Fig. 1. Philometra sp. from gonads of Argyrosomus regius, subgravid female. Anterior end of (A) larger (439 mm long) and (B) smaller $(180 \mathrm{~mm})$ specimens. Cephalic end of $(C)$ larger and $(E)$ smaller specimens, lateral views. (D) Cephalic end, apical view (reconstructed from SEM micrograph). (F) Outline of caudal end of smaller specimen, lateral view. (G) Caudal end of larger specimen, lateral view. Scale bars: $(A, B)=500 \mu m_{i}(C, E)=100 \mu m_{i}(D)=30 \mu m_{i}(F, G)=300 \mu \mathrm{m}$ 


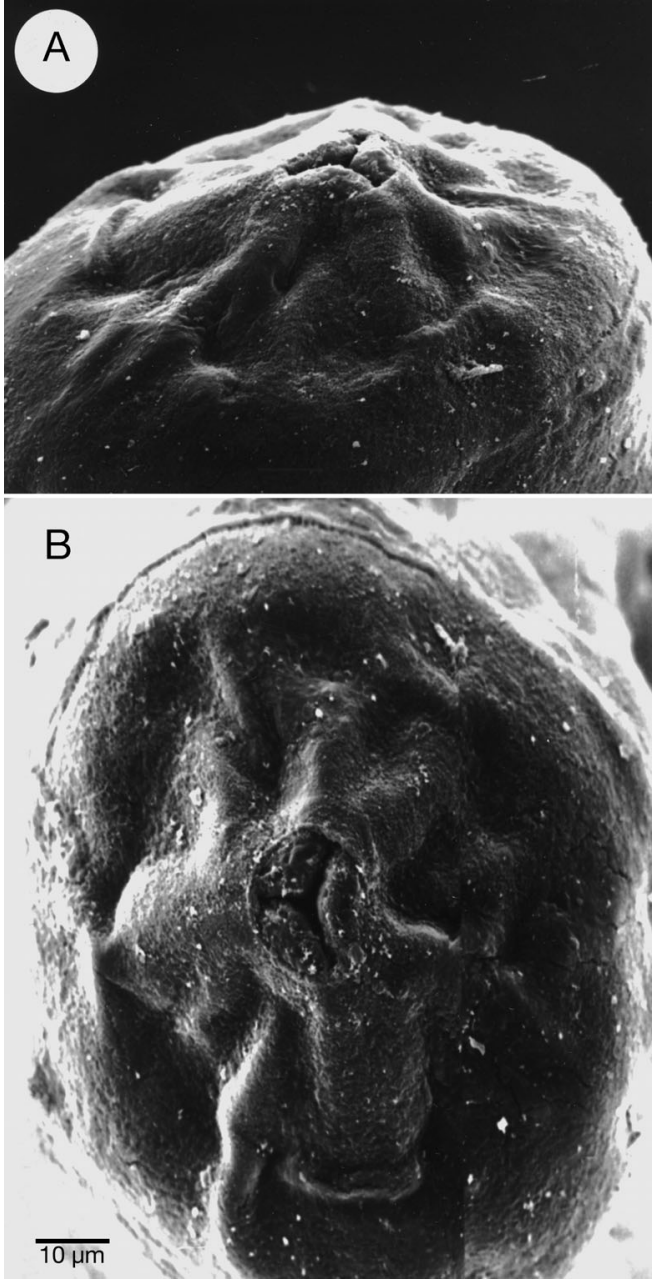

Fig. 2. Philometra sp. from gonads of Argyrosomus regius. SEM micrographs of cephalic end of subgravid female. (A) Dorsal and (B) apical views

the dorsal oesophageal gland extends anteriorly to the level of the nerve ring and posteriorly to the small ventriculus, which measures $30 \times 81 \mu \mathrm{m}$ in the larger specimen. The nerve ring is 340 to $394 \mu \mathrm{m}$ from the anterior body end. The intestine is dark brown; its posterior end is atrophied, forming a ligament attached ventrally to the body wall near the posterior extremity (Fig. 1G). The posterior end of the body is rounded, 109 to $136 \mu \mathrm{m}$ wide, with 2 outlined lateral minute papillalike caudal protrusions, found only in the larger specimen. The vagina and vulva are absent. The 2 ovaries are rather long and thin and are situated near the anterior and posterior ends of the body. The uterus occupies most of the body and is filled with eggs and developing embryos.

The general female morphology of these nematodes is similar to that of Philometra lateolabracis (Yamaguti, 1935), a widespread, gonad-infecting parasite of many species of marine fishes, reported from different parts of the world. However, the maximum body length of the gravid (larvigerous) female of $P$. lateolabracis is only $230 \mathrm{~mm}$ (Moravec 2006), whereas one of the subgravid (ovigerous) females in the present study is nearly double that length (439 mm). Accordingly, conspecific gravid females with larvae can be expected to be even longer. Since the conspecific males are not yet known, the exact species identification of these Portuguese nematodes will only be possible when new material from this fish species, including betterpreserved specimens, both males and gravid females, is collected.

The Philometra specimens now collected from Argyrosomus regius represent the first detailed record of this nematode presence in perciforms from the NorthEastern Atlantic. Santos (1996) reports on 'a viviparous nematode $8 \mathrm{~cm}$ long' (probably a Philometra female) found in the body cavity of the European seabass, Dicentrarchus labrax (Linnaeus) (Moronidae) off the Portuguese coast. However, its location in the host suggests that it belonged to a different species than nematodes found in the present study (Moravec 2006). 'Very long nematodes' parasitic of $A$. regius have been reported in the gas bladder, stomach-walls and ovaries of fish caught off Mauritania (Tixerant 1974) but no such evidence was observed in the current specimens. On the other hand, Hermas (1995) presents a photograph of a similarly 'long nematode' found in male and female A. regius gonads off Agadir on the Moroccan Atlantic coast. Her work does not, however, provide detailed description of such specimens, so their taxonomic identification to family or genus is impossible. However, Philometra has been recorded in gonads of wild A. japonicus captured off the Western Australian coast where its prevalence was over $50 \%$ in mature specimens of both sexes (Farmer 2003). In the present work histological analysis of parasite gonads was not performed, so effective parasite damage to fish gonads could not be assessed. However, severe infections by these pathogenic parasites sometimes cause serious damage to the fish ovaries and thus may affect reproductive output at individual and population levels (Hine \& Anderson 1982, Sakaguchi et al. 1987, Moravec et al. 2003, Clarke et al. 2006).

The exact identification of the Philometra species, its prevalence and eventual deleterious effects on Argyrosomus regius reproduction remain unknown. Given that (1) species of Philometra may prove to be significant pathogens in fish cultures, (2) A. regius is increasingly popular in Southern European aquaculture, and (3) mature A. regius female gonads are frequently used for human consumption throughout its distribution range, the authors suggest that a further, more detailed taxonomic and ecological study of this nematode parasite should be attempted in the near future. 
Acknowledgements. Thanks to the staff of the Laboratory of Electron Microscopy of the Institute of Parasitology, Biology Centre of the ASCR, in České Budějovice for their technical assistance, and to I. Husáková from the Department of Helminthology of the same Institute for her help with the preparation of illustrations. This study was partly supported by the Grant Agency of the Czech Republic (grant no. 524/06/0170) and by the research projects of the Institute of Parasitology, BC ASCR (Z60220518 and LC522). Additional support came from the Portuguese Science and Technology Foundation (FCT) to N.P. (grant no. BD/12550/2003), and research project CORV no. 22-05-01-FDR-00036 from the Portuguese Fisheries Directorate (DGPA).

\section{LITERATURE CITED}

Clarke LM, Dove ADM, Conover DO (2006) Prevalence, intensity, and effect of a nematode (Philometra saltatrix) in the ovaries of bluefish (Pomatomus saltatrix). Fish Bull 104:118-124

Costa MJ, Cabral H, Costa JL, Prista N, Lopes JC (2006) Corvina-legítima Argyrosomus regius, dados biológicos para a gestão e a produção de um recurso. Progress Report (Ref: 22-05-01-FDR-00036). DGPA, Lisboa

Farmer B (2003) Biology of the mulloway Argyrosomus japonicus in Western Australia. Honours dissertation, Murdoch University, Murdoch

Hermas J (1995) Contribution a l'étude des débarquements et de la biologie du maigre Argyrosomus regius (Asso, 1801) au port d'Agadir. 3ème Cycle Thesis, Université Ibnou Zohr, Agadir

Hine PM, Anderson CD (1982) Diseases of the gonads and kidneys of New Zealand snapper, Chrysophrys auratus Forster (F. Sparidae). In: Fowler ME (ed) Wildlife diseases of the Pacific basin and other countries. Academic Press, London, p 166-170

Janiszewska J (1949) Some fish nematodes from the Adriatic Sea. Zool Polon 5:7-30

Kovaleva AA, Khromova LA (1967) On the biology of Philometra globiceps (Rudolphi, 1819) (Nematoda: Dracunculoidea). In: Problems in parasitology. Naukova Dumka, Kiev, p 472-473 (in Russian)

López-Neyra CR (1951) Sanguinofilaria jordani n. sp. (Nematoda; Filaroidea). Bol Univ Granada, Farmacia, 291-293

Merella P, Reñones O, Garippa G (2004) Finding of one male Philometra lateolabracis (Nematoda: Philometridae) parasite on the dusky grouper Epinephelus marginatus (Osteichthyes: Serranidae) in the western Mediterranean. Parassitologia 46(Suppl 1):158

Editorial responsibility: Robin Overstreet, Ocean Springs, Mississippi, USA
Moravec F (2006) Dracunculoid and anguillicoloid nematodes parasitic in vertebrates. Academia, Prague

Moravec F, Genc E (2004) Redescription of three Philometra spp. (Nematoda, Philometridae) from the gonads of marine perciform fishes of Iskenderun Bay (North-East Mediterranean), Turkey. Acta Parasitol 49:31-40

Moravec F, Salgado-Maldonado G (2007) A new species of Philometra (Nematoda: Philometridae) from the gonads of the rock hind Epinephelus adscensionis (Osteichthyes) from the southern Gulf of Mexico, Mexico. Acta Parasitol (in press)

Moravec F, Glamuzina B, Marino G, Merella P, Di Cave D (2003) Occurrence of Philometra lateolabracis (Nematoda: Philometridae) in the gonads of marine perciform fishes in the Mediterranean region. Dis Aquat Org 53: 267-269

Moravec F, de Buron I, Roumillat WA (2006a) Two new species of Philometra (Nematoda: Philometridae) parasitic in the perciform fish Cynoscion nebulosus (Sciaenidae) in the estuaries of South Carolina, USA. Folia Parasitol 53: $63-70$

Moravec F, Ternengo S, Levron C (2006b) Three species of Philometra (Nematoda: Philometridae) from marine fishes off Corsica, France. Acta Parasitol 51:111-118

Petter AJ, Radujkovic BM (1986) Nématodes parasites de poissons de la mer Adriatique. Bull Mus Natl Hist Nat, 4e sér, sect A, 8:487-499

Petter AJ, Radujkovic BM (1989) Parasites des poissons marins du Montenegro: nématodes. Acta Adriat 30: 195-236

Quéméner L (2002) Le maigre commun (Argyrosomus regius): biologie, pêche, marché et potentiel aquacole. IFREMER, Plouzané

Rudolphi CA (1819) Entozoorum synopsis cui accedunt mantesia duplex et indices locupletissimi. Subtimus Augusti Rucker, Berlin

Sakaguchi S, Yamagata Y, Sako H (1987) Reidentification of Philometra parasitic on the Red Sea bream. Bull Natl Res Inst Aquac 12:69-72 (in Japanese with English abstract)

Santos MJ (1996) Observations on the parasitofauna of wild sea bass (Dicentrarchus labrax L.) from Portugal. Bull Eur Assoc Fish Pathol 16:77-79

Stossich M (1896) Ricerche elmintologiche. Boll Soc Adriat Sci Nat 17:121-136

Tixerant G (1974) Contribution à l'étude de la biologie du maigre ou courbine (Argyrosomus regius Asso $=$ Sciaena aquila Lacépède) sur la côte Mauritanienne. PhD thesis, Université d'Aix-Marseille, Marseille

Willemoes-Suhm R (1871) Ueber einige Trematoden und Nemathelminthen. Z Wiss Zool 21:175-203 (Plates 11-13)

Submitted: May 24, 2007; Accepted: August 11, 2007

Proofs received from author(s): October 17, 2007 